\title{
Sporminarins A and B: Antifungal Metabolites from a Fungicolous Isolate of Sporormiella minimoides
}

\author{
Sanjay V. Mudur, James B. Gloer, Donald T. Wicklow \\ This manuscript is dedicated to the late Professor Kenneth L. Rinehart, Jr. of the \\ University of Illinois in honor of his many contributions to our field.
}

Received: June 1, 2006 / Accepted: August 16, 2006

(C) Japan Antibiotics Research Association

\begin{abstract}
Cultures of a fungicolous isolate of Sporormiella minimoides afforded two new polyketide metabolites which we have named sporminarins A (1) and B (2). The planar structures of $\mathbf{1}$ and $\mathbf{2}$ were elucidated by analysis of NMR and MS data, and by chemical methods. 1 exhibited significant antifungal activity against Aspergillus flavus.
\end{abstract}

Keywords sporminarins, antifungal, Sporormiella minimoides

\section{Introduction}

Our ongoing studies of mycoparasitic and fungicolous fungi have shown them to be excellent sources of new biologically active natural products $[1 \sim 4]$. In the course of this ongoing project, we examined cultures of a fungicolous isolate of Sporormiella minimoides Ahmed \& Cain (Sporormiaceae; NRRL 37629) that was obtained from a basidioma of Trametes hirsutum collected from a dead hardwood branch in a subalpine dry forest in Hawaii. The ethyl acetate extract obtained from solid-state fermentation cultures of $S$. minimoides exhibited antifungal activity against Aspergillus flavus. The extract was fractionated using silica gel column chromatography, and the resulting fractions were subjected to reversed-phase HPLC to yield two new metabolites, which we have named sporminarins A (1) and B (2). The known compound brocaenol A was also obtained, and was identified by comparison of NMR and MS data with literature values [5]. Details of the isolation, structure elucidation, and bioactivities of $\mathbf{1}$ and $\mathbf{2}$ are presented here.

\section{Results and Discussion}

Sporminarin A (1) was assigned a molecular formula of $\mathrm{C}_{36} \mathrm{H}_{62} \mathrm{O}_{8}$ (six degrees of unsaturation) on the basis of NMR (Table 1) and HRESIMS data. ${ }^{1} \mathrm{H}$ NMR analysis of $\mathbf{1}$ in $\mathrm{CDCl}_{3}$ gave poor spectra, with considerable overlap and broad signals, but spectra recorded in $\mathrm{CD}_{3} \mathrm{OD}$ were of much better quality. ${ }^{1} \mathrm{H},{ }^{13} \mathrm{C} \mathrm{NMR}$, and DEPT data for $\mathbf{1}$ revealed the presence of six olefinic protons, five oxymethines, six non-oxygenated methines, three nonoxygenated methylenes, and 11 methyl groups. These units accounted for 56 protons, indicating that the remaining six protons must be exchangeable. The methyl group ${ }^{1} \mathrm{H}$ NMR signals consisted of two olefinic methyl resonances lacking vicinal coupling, two aliphatic methyl singlets, six $\mathrm{CH}_{3}-\mathrm{CH}$ doublets, and one $\mathrm{CH}_{3}-\mathrm{CH}_{2}$ triplet. The ${ }^{13} \mathrm{C}$ NMR spectrum of 1 revealed 35 discrete signals, one short of the expected count, suggesting that two of the signals were coincident. Only seven signals were distinguishable in the olefinic region of the ${ }^{13} \mathrm{C} \mathrm{NMR}$ spectrum of $\mathbf{1}$, and the DEPT spectrum contained six of those signals, indicating that the overlapped signal must correspond to one of two nonprotonated olefinic carbons. The ${ }^{13} \mathrm{C}$ NMR and DEPT data
J. B. Gloer (Corresponding author), S. V. Mudur: Department of Chemistry, University of Iowa, Iowa City, Iowa 52242, E-mail: james-gloer@uiowa.edu.
D. T. Wicklow: Mycotoxin and Crop Bioprotection Research Units, Agricultural Research Service, National Center for Agricultural Utilization Research, USDA, Peoria, Illinois 61604 
Table 1 NMR Data for sporminarins $A(\mathbf{1})$ and $B(2)$ acquired in $C_{3} O D$

\begin{tabular}{|c|c|c|c|c|c|c|}
\hline \multirow{2}{*}{ Position } & \multicolumn{3}{|c|}{ Sporminarin A (1) } & \multicolumn{3}{|c|}{ Sporminarin B (2) } \\
\hline & $\delta_{\mathrm{H}}(\text { mult.; } J \text { in } \mathrm{Hz})^{a}$ & $\delta_{C}^{b, c}$ & 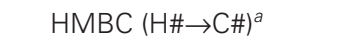 & 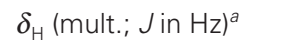 & $\delta_{C}^{b, c}$ & 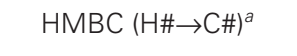 \\
\hline 1 & & 179.9 & & & 179.1 & \\
\hline 2 & $2.54(\mathrm{~m})$ & 44.9 & 1,3 & 2.47 (quintet; 7.5) & 47.5 & $1,3,4,2-\mathrm{CH}_{3}$ \\
\hline 3 & $4.05(d ; 9.3)$ & 81.7 & $2,5,4-\mathrm{CH}_{3}$ & $4.15(t ; 7.5)$ & 76.1 & $1,2,4,2-\mathrm{CH}_{3}$ \\
\hline 4 & & $136.4^{d}$ & & $5.45(\mathrm{dd} ; 15,7.5)$ & 131.9 & $2,3,6$ \\
\hline 5 & $5.32(d ; 9.7)$ & 133.7 & $3,6,7,4-\mathrm{CH}_{3}, 6-\mathrm{CH}_{3}$ & 5.68 (dd; 15, 7.5) & $137.6^{h}$ & $3,6,7,6-\mathrm{CH}_{3}$ \\
\hline 6 & 2.52 (dquintet; 9.7, 7) & 39.7 & $4,5,7,6-\mathrm{CH}_{3}$ & 2.26 (sextet; 7.5) & 44.2 & 7 \\
\hline 7 & $3.83(\mathrm{t} ; 7)$ & $78.4^{e}$ & $5,6,6-\mathrm{CH}_{3}$ & $3.85(t ; 7.5)$ & 77.9 & $6,6-\mathrm{CH}_{3}$ \\
\hline 8 & $5.49(\mathrm{dd} ; 15,7)$ & $132.9^{f}$ & 6 & $5.48(d d ; 15,7.5)$ & $132.6^{i}$ & 6,7 \\
\hline 9 & $5.63(d d ; 15,7.9)$ & 136.7 & $10,10-\mathrm{CH}_{3}$ & $5.62(d d ; 15,7.5)$ & $136.5^{j}$ & $10,10-\mathrm{CH}_{3}$ \\
\hline 10 & $2.25(\mathrm{~m})$ & 44.2 & $9,11,10-\mathrm{CH}_{3}$ & 2.26 (overlapped) & 44.2 & \\
\hline 11 & $3.84(\mathrm{t} ; 7)$ & $78.2^{e}$ & $10,10-\mathrm{CH}_{3}$ & $3.84(t ; 7.5)$ & 78.2 & $10,10-\mathrm{CH}_{3}$ \\
\hline 12 & $5.49(\mathrm{dd} ; 15,7)$ & $132.7^{f}$ & $14,15^{\prime}$ & 5.49 (dd; 15, 7.5) & $132.7^{i}$ & $10,11,14$ \\
\hline 13 & $5.62(d d ; 15,7.9)$ & 137.7 & $14,15,14-\mathrm{CH}_{3}$ & $5.62(d d ; 15,7.9)$ & $137.4^{h}$ & $14,15,14-\mathrm{CH}_{3}$ \\
\hline 14 & $2.30(\mathrm{~m})$ & 41.7 & $12,15,14-\mathrm{CH}_{3}$ & $2.29(\mathrm{~m})$ & 41.6 & $12,15,14-\mathrm{CH}_{3}$ \\
\hline 15 & $3.57(d ; 8.8)$ & 84.5 & $14,17,14-\mathrm{CH}_{3}, 16-\mathrm{CH}_{3}$ & $3.57(\mathrm{~d} ; 8.8)$ & 84.5 & $14,14-\mathrm{CH}_{3}, 16-\mathrm{CH}_{3}$ \\
\hline 16 & & 137.8 & & & 137.8 & \\
\hline 17 & $5.62(\mathrm{br} \mathrm{s})$ & $136.4^{d}$ & $15,19,16-\mathrm{CH}_{3}, 18-\mathrm{CH}_{3}$ & 5.62 (br s) & $136.4^{j}$ & $15,19,16-\mathrm{CH}_{3}, 18-\mathrm{CH}_{3}$ \\
\hline 18 & & 78.3 & & & 78.3 & \\
\hline 19 & $3.01(d ; 10.6)$ & 81.5 & $17,21,18-\mathrm{CH}_{3}, 20-\mathrm{CH}_{3}$ & $3.01(d ; 10.6)$ & 81.5 & $21,18-\mathrm{CH}_{3}, 20-\mathrm{CH}_{3}$ \\
\hline 20 & $1.95(\mathrm{~m})$ & 29.8 & $18,19,21,20-\mathrm{CH}_{3}$ & $1.95(\mathrm{~m})$ & 29.8 & $19,21,20-\mathrm{CH}_{3}$ \\
\hline $21 \beta$ & 1.55 (dd; 13, 3.6) & 45.8 & $19,20,22,20-\mathrm{CH}_{3}, 22-\mathrm{CH}_{3}$ & 1.55 (dd; 13, 3.6) & 45.8 & $20,22,20-\mathrm{CH}_{3}, 22-\mathrm{CH}_{3}$ \\
\hline $21 \alpha$ & $1.30(\mathrm{~m})$ & & $19,20,23,20-\mathrm{CH}_{3}, 22-\mathrm{CH}_{3}$ & $1.30(\mathrm{~m})$ & & $19,20,23,20-\mathrm{CH}_{3}$ \\
\hline 22 & & 75.7 & & & 75.7 & \\
\hline $23 a$ & $1.40(\mathrm{~m})$ & 54.0 & $21,22,25,22-\mathrm{CH}_{3}$ & $1.40(\mathrm{~m})$ & 54.0 & $21,22,25,22-\mathrm{CH}_{3}$ \\
\hline $23 b$ & $1.27(\mathrm{dd} ; 14,6.4)$ & & $21,22,24,22-\mathrm{CH}_{3}, 24-\mathrm{CH}_{3}$ & $1.27(\mathrm{dd} ; 14,6.4)$ & & $21,22,24,25,24-\mathrm{CH}_{3}$ \\
\hline 24 & $1.61(\mathrm{~m})$ & 31.4 & $22,23,25,26,24-\mathrm{CH}_{3}$ & $1.61(\mathrm{~m})$ & 31.4 & $22,23,25,26,24-\mathrm{CH}_{3}$ \\
\hline $25 a$ & $1.40(\mathrm{~m})$ & 33.0 & 23,26 & $1.40(\mathrm{~m})$ & 33.0 & 23,26 \\
\hline $25 b$ & 1.14 (dquintet; 14, 7.4) & & $23,24,26,24-\mathrm{CH}_{3}$ & 1.14 (dquintet; 14, 7.4) & & $23,24,26,24-\mathrm{CH}_{3}$ \\
\hline 26 & $0.85(t ; 7.4)$ & 12.1 & 24,25 & $0.85(t ; 7.4)$ & 12.1 & 24,25 \\
\hline $2-\mathrm{CH}_{3}$ & $0.96(d ; 6.8)$ & 15.1 & $1,2,3$ & $1.07(\mathrm{~d} ; 7.5)$ & 14.2 & $1,2,3$ \\
\hline $4-\mathrm{CH}_{3}$ & 1.62 (s) & 11.1 & $3,4,5$ & & & \\
\hline $6-\mathrm{CH}_{3}$ & $0.92(d ; 7)$ & $17.3^{g}$ & $5,6,7$ & $0.98(d ; 7.5)$ & $17.1^{k}$ & $5,6,7$ \\
\hline $10-\mathrm{CH}_{3}$ & $0.98(d ; 6.9)$ & $17.1^{g}$ & $9,10,11$ & $0.98(d ; 7.5)$ & $16.9^{k}$ & $9,10,11$ \\
\hline $14-\mathrm{CH}_{3}$ & $0.87(d ; 6.8)$ & 18.0 & $13,14,15$ & $0.87(\mathrm{~d} ; 6.8)$ & 18.0 & $13,14,15$ \\
\hline $16-\mathrm{CH}_{3}$ & $1.83(\mathrm{~d} ; 1.1)$ & 13.1 & $15,16,17$ & $1.83(\mathrm{~d} ; 1.2)$ & 13.1 & $15,16,17$ \\
\hline $18-\mathrm{CH}_{3}$ & 1.40 (s) & 22.8 & $17,18,19$ & 1.40 (s) & 22.8 & $17,18,19$ \\
\hline $20-\mathrm{CH}_{3}$ & $1.02(d ; 6.3)$ & 19.3 & $19,20,21$ & $1.02(\mathrm{~d} ; 6.3)$ & 19.3 & $19,20,21$ \\
\hline $22-\mathrm{CH}_{3}$ & 1.30 (s) & 27.6 & $21,22,23$ & 1.30 (s) & 27.6 & $21,22,23$ \\
\hline $24-\mathrm{CH}_{3}$ & $0.92(d ; 7)$ & 22.4 & $23,24,25$ & $0.92(d ; 6.7)$ & 22.4 & $23,24,25$ \\
\hline
\end{tabular}

${ }^{a}$ Recorded at $600 \mathrm{MHz} .{ }^{b}$ Recorded at $100 \mathrm{MHz} .{ }^{c}$ Multiplicities were assigned on the basis of DEPT data and are consistent with the assignments. ${ }^{d \sim k}$ Assignments with identical superscripts are interchangeable. 'This four-bond correlation was relatively weak, but was clearly observed.

also revealed the presence of two oxygenated quaternary $s p^{3}$ carbons, and an oxycarbonyl carbon $\left(\delta_{\mathrm{C}} 179.9\right)$ that was presumed to be a carboxylic acid group, although chemical shift alone could not definitively rule out an ester unit [6]. Treatment of $\mathbf{1}$ with trimethylsilyldiazomethane yielded the corresponding methyl ester $\left(\mathrm{COOCH}_{3}\right.$ methyl signal at $\delta_{\mathrm{H}}$ 3.69), thereby confirming the presence of the carboxylic acid group. Of the six degrees of unsaturation required by the molecular formula of $\mathbf{1}$, five were accounted for by the above units, indicating that $\mathbf{1}$ must contain a ring. The 
planar structure of $\mathbf{1}$ was ultimately assigned by analysis of HMBC and HMQC data, together with chemical methods, as described below.

Characteristic two- and three-bond HMBC correlations observed for the methyl proton signals (Table 1) were instrumental in the construction of three structural subunits that were ultimately linked together to arrive at the planar structure of $\mathbf{1}$. All of the methyl signals except for two overlapping signals at $\delta 0.92\left(6-\mathrm{CH}_{3}\right.$ and $\left.24-\mathrm{CH}_{3}\right)$ were sufficiently resolved at $600 \mathrm{MHz}$ to give unambiguous sets of correlations. HMBC correlations from H-5, H-6, and $\mathrm{H}-$ 7 to $6-\mathrm{CH}_{3}$ and from $\mathrm{H}-23 \mathrm{~b}, \mathrm{H}-24$, and $\mathrm{H}-25 \mathrm{~b}$ to $24-\mathrm{CH}_{3}$ permitted location of these two methyl groups, and enabled assignment of the corresponding crosspeaks for each of these $\mathrm{CH}_{3}$ proton signals. Subunit $\mathrm{A}(\mathrm{C} 1 \sim \mathrm{C} 7)$ in $\mathbf{1}$ was readily constructed by analysis of $\mathrm{HMBC}$ correlations observed for the 2- $\mathrm{CH}_{3}, 4-\mathrm{CH}_{3}$, and $6-\mathrm{CH}_{3}$ signals. Specifically, the 2- $\mathrm{CH}_{3}$ doublet showed correlations to carboxylic acid carbon $\mathrm{C}-1$, methine $\mathrm{C}-2$, and oxymethine $\mathrm{C}-3$. The 4- $\mathrm{CH}_{3}$ singlet displayed HMBC correlations to C3 and to two $s p^{2}$ carbons (C-4 and C-5), one of which ( $\delta$ 136.4) proved to be coincident with another, as noted above. Since the $4-\mathrm{CH}_{3}$ signal lacks vicinal coupling, it cannot be attached to protonated carbon $\mathrm{C}-5$. The $4-\mathrm{CH}_{3}$ must therefore be attached to $\mathrm{C}-4$, which must be nonprotonated. The coincident signal at $\delta 136.4$ could then be assigned as a protonated olefinic carbon elsewhere in the molecule (C-17), since a signal at this position appeared in the DEPT spectrum. Correlations of 6- $\mathrm{CH}_{3}$ with $\mathrm{C}-5, \mathrm{C}-6$, and $\mathrm{C}-7$ completed subunit $\mathrm{A}$. In a similar manner, observation of all possible two- and three-bond HMBC correlations for 14- $\mathrm{CH}_{3}, 16-\mathrm{CH}_{3}, 18-\mathrm{CH}_{3}, 20-\mathrm{CH}_{3}, 22-\mathrm{CH}_{3}$, 24- $\mathrm{CH}_{3}$, and $\mathrm{H}_{3}-26$, together with reciprocal correlations between $\mathrm{CH}-12$ and $\mathrm{CH}-14$ led to the straightforward construction of subunit B $(\mathrm{C} 12 \sim \mathrm{C} 26)$. The remaining groups (corresponding to a disubstituted double bond, an oxymethine, a non-oxygenated methine, and a methyl group) were assembled as subunit $\mathrm{C}(\mathrm{C} 8 \sim \mathrm{C} 11)$ with the aid of HMBC correlations of $10-\mathrm{CH}_{3}$ to $\mathrm{C}-9, \mathrm{C}-10$, and C11 and that of $\mathrm{H}-9$ to $10-\mathrm{CH}_{3}$. Although insertion of subunit $\mathrm{C}$ between subunits $\mathrm{A}$ and $\mathrm{B}$ could be presumed based upon the expected arrangement of acetate units in polyketide biosynthesis, the attachment of C-7 to C-8 (and therefore of $\mathrm{C}-11$ to $\mathrm{C}-12$ by default) was nonetheless unambiguously confirmed by observation of an HMBC correlation from $\mathrm{H}-8$ to C-6.

The six exchangeable protons in the molecule must be accounted for by the carboxylic acid functionality (C-1) and five hydroxy groups. These units would also account for seven oxygen atoms, indicating that the remaining oxygen atom must be shared by two carbons to form an ether linkage. In order to identify the carbons bearing the five hydroxy groups, 1 was treated with acetic anhydride, leading to formation of a pentaacetate (3; ESIMS M+Na ${ }^{+}$ ion at $m / z$ 855). The ${ }^{1} \mathrm{H}$ NMR spectrum of this product displayed significant downfield shifts for all five oxymethine signals (H-3, H-7, H-11, H-15, and H-19) relative to their positions in the spectrum of $\mathbf{1}$, indicating that the corresponding carbons bear $\mathrm{OH}$ groups in $\mathbf{1}$. The only remaining oxygenated carbons (C-18 and C-22) must therefore be connected via an ether linkage to form a tetrahydropyran ring. However, because C-18 and C-22 are both quaternary carbons, it was not possible to obtain direct evidence for this connection from HMBC data. ${ }^{1} \mathrm{H}$ NMR $J$ values and NOESY data (see below) were fully consistent with the presence of a tetrahydropyran ring adopting the expected chair conformation. Even so, the inability to directly demonstrate this ether linkage via HMBC data raised the concept of a possible alternative acyclic structure, wherein the ether linkage was replaced by two tertiary $\mathrm{OH}$ groups. Such a structure would have a formula 18 mass units higher than structure $\mathbf{1}$, and no trace of a corresponding ion was observed in the ESI mass spectrum, but it was conceivable that the presumed $(\mathrm{M}+\mathrm{Na})^{+}$ion observed in the ESI mass spectrum of $\mathbf{1}$ was actually a pseudomolecular ion peak resulting from unusually facile loss of a water molecule. In addition, standard acetylation conditions would not be expected to acetylate tertiary hydroxy groups. Efforts to observe $\mathrm{OH}$ resonances by recording the ${ }^{1} \mathrm{H}$ NMR spectrum of $\mathbf{1}$ in DMSO- $d_{6}$ gave inconclusive results, as the exchangeable signals were very broad and overlapped. Thus, in order to address this issue, ESIMS experiments employing deuterium-exchanged samples of $\mathbf{1}$ and its pentaacetate (3) were carried out. The samples were dissolved in $\mathrm{D}_{2} \mathrm{O}-\mathrm{CD}_{3} \mathrm{OD}(1: 1)$, and the solutions were used directly for MS to prevent any possible back-exchange of protons. If the mass of the neutral

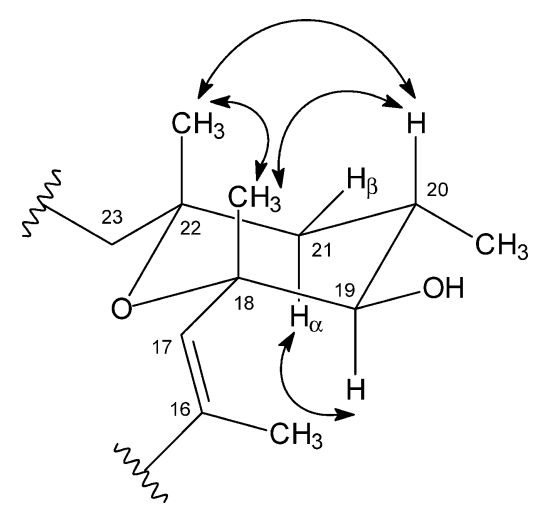

Fig. 1 Key NOESY correlations for the ring in sporminarin A (1). 


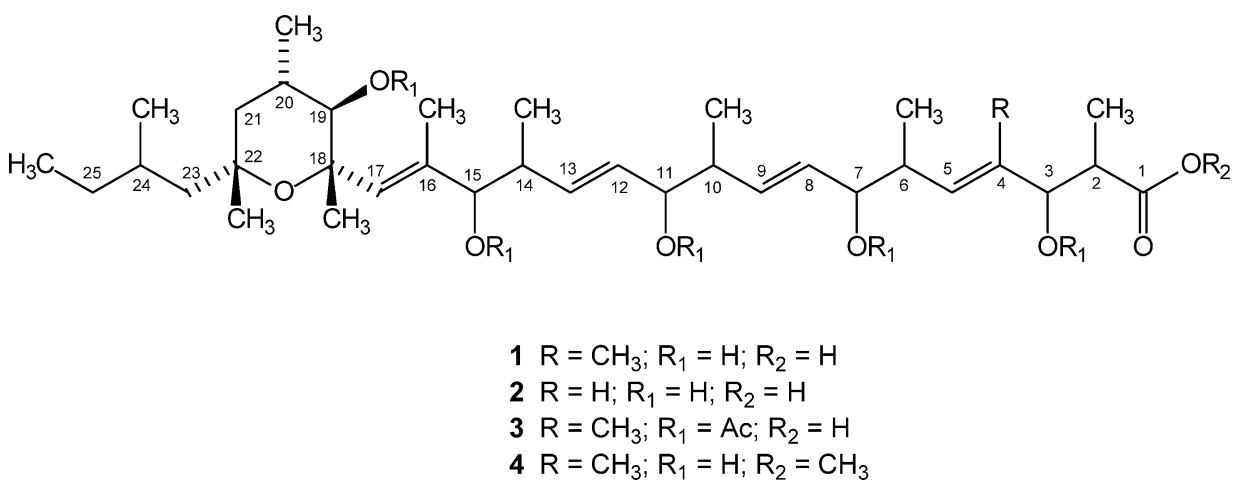

product was truly $640\left(\mathrm{C}_{36} \mathrm{H}_{64} \mathrm{O}_{9}\right)$ rather than 622 $\left(\mathrm{C}_{36} \mathrm{H}_{62} \mathrm{O}_{8}\right)$, and there were eight exchangeable protons rather than six, deuterium-exchanged samples of $\mathbf{1}$ and $\mathbf{3}$ would be expected to show $(\mathrm{M}-\mathrm{HDO}+\mathrm{Na})^{+}$ion peaks at $m / z 652$ and 857, respectively. However, these samples exhibited clean $(\mathrm{M}+\mathrm{Na})^{+}$ion peaks at $m / z 651$ and 856, respectively, and $(\mathrm{M}-\mathrm{D})^{-}$ion peaks at $m / z 626$ and 831 , respectively. This result provided further support for the presence of the tetrahydropyran ring in the structure of $\mathbf{1}$.

Stereochemical features of $\mathbf{1}$ were proposed on the basis of analysis of 1D NMR and NOESY data. The geometry of both of the disubstituted double bonds was assigned as $E$ based on $J_{\mathrm{H} 8-\mathrm{H} 9}$ and $J_{\mathrm{H} 12-\mathrm{H} 13}$ values of $15 \mathrm{~Hz}$. Upfield chemical shifts for olefinic methyl carbons $4-\mathrm{CH}_{3}(\delta 11.1)$ and $16-\mathrm{CH}_{3}(\delta 13.1)$ allowed assignment of the $E$-geometry of both trisubstituted double bonds [7]. The relative configurations of the stereocenters in the ring were proposed by analysis of relevant vicinal coupling constants and NOESY correlations. The large $J$-value $(10.6 \mathrm{~Hz})$ between $\mathrm{H}-19$ and $\mathrm{H}-20$ indicated that these two protons must have axial orientations, and placed the $20-\mathrm{CH}_{3}$ and the 19-OH groups in equatorial orientations trans to each other. Strong mutual NOESY crosspeaks (Figure 1) correlating $\mathrm{H}-20,18-\mathrm{CH}_{3}$, and $22-\mathrm{CH}_{3}$ positioned these groups on the same $(\beta)$ face of the ring. A 1,3-diaxial relationship between the $18-\mathrm{CH}_{3}$ and $22-\mathrm{CH}_{3}$ methyl groups is consistent with the assumption that the ring in $\mathbf{1}$ would adopt a chair conformation that places the bulkier sidechains in equatorial orientations.

The relative configurations of the other stereocenters were more difficult to evaluate due to the acyclic nature of the remainder of the molecule. Since these assignments could not be made (or related to others in the molecule) with confidence, no definitive assignments are made here. However, some proposals can be made about selected stereocenters (e.g., $\mathrm{C} 2 \sim \mathrm{C} 3$ and $\mathrm{C} 14 \sim \mathrm{C} 15)$ on the basis of $J$-based configurational analysis [8]. The vicinal coupling constant between $\mathrm{H}-2$ and $\mathrm{H}-3(9.3 \mathrm{~Hz})$ suggested a conformational preference that places the $\mathrm{H} 2 \sim \mathrm{H} 3$ dihedral angle close to $180^{\circ}$. In conjunction with this observation, NOESY correlations between 4- $\mathrm{CH}_{3}$ and $2-\mathrm{CH}_{3}$ suggested a relative configuration placing the $2-\mathrm{CH}_{3}$ and the $3-\mathrm{OH}$ groups anti to each other. A similar conclusion was derived for the $\mathrm{C} 14 \sim \mathrm{C} 15$ stereocenters based on a similar coupling constant between $\mathrm{H}-14$ and $\mathrm{H}-15(8.8 \mathrm{~Hz})$ and analogous NOESY correlations between $14-\mathrm{CH}_{3}$ and $16-\mathrm{CH}_{3}$. However, the corresponding ${ }^{3} J$-values at other, structurally similar sites in the molecule were considered less definitive (e.g., $7 \mathrm{~Hz}$ values for $J_{\mathrm{H} 6-\mathrm{H} 7}$ and $J_{\mathrm{H} 10-\mathrm{H} 11}$ ), so relative configurations at these positions were not proposed.

The molecular formula of the second metabolite, sporminarin $\mathrm{B}$ (2), was assigned as $\mathrm{C}_{35} \mathrm{H}_{60} \mathrm{O}_{8}$ (six degrees of unsaturation) on the basis of 1D NMR (Table 1) and HRESIMS data. The ${ }^{1} \mathrm{H}$ NMR spectrum of $\mathbf{2}$ was nearly identical to that of $\mathbf{1}$. However, absence of an olefinic methyl signal near $\delta 1.62$ and the appearance of a new vinylic proton signal $(\delta 5.45)$ in the ${ }^{1} \mathrm{H}$ NMR spectrum of 2 suggested that the methyl group $4-\mathrm{CH}_{3}$ in $\mathbf{1}$ had been replaced by a proton in $\mathbf{2}$. This was corroborated by the fact that the proton signal for the nearby oxymethine that was observed as a doublet ( $\delta$ 4.05, H-3) in the ${ }^{1} \mathrm{H}$ NMR spectrum of 1 appeared as a triplet $(\delta 4.15)$ in the spectrum of $\mathbf{2}$. The ${ }^{13} \mathrm{C}$ NMR spectrum of $\mathbf{2}$ was also very similar to that of $\mathbf{1}$, and revealed only 34 distinguishable signals, again suggesting signal overlap. The structure of $\mathbf{2}$ was independently verified by detailed analysis of the HMBC (Table 1) and HMQC data in a fashion analogous to that applied in the structure elucidation of $\mathbf{1}$. For example, HMBC correlations of 2- $\mathrm{CH}_{3}$ to $\mathrm{C}-1, \mathrm{C}-2$, and $\mathrm{C}-3, \mathrm{H}-2$ to $\mathrm{C}-4, \mathrm{H}-3$ to $\mathrm{C}-4$, and of $\mathrm{H}-5$ to $\mathrm{C}-3, \mathrm{C}-6, \mathrm{C}-7$, and $6-\mathrm{CH}_{3}$ allowed construction of a subunit corresponding to the $\mathrm{C} 1 \sim \mathrm{C} 7$ unit of 2 . Further analysis of the data confirmed that the remainder of the structure matched that of $\mathbf{1}$. Additionally, the two coincident signals were found to correspond to non-oxygenated methines C- 6 and C-10 ( $\delta$ 44.2) based on observation of HMQC data for H-6 and H10 , and $\mathrm{HMBC}$ correlations of $6-\mathrm{CH}_{3}$ and $10-\mathrm{CH}_{3}$ to $\mathrm{C}-6$ and $\mathrm{C}-10$, respectively, together with an $\mathrm{HMBC}$ correlation 
of $\mathrm{H}-9$ to $\mathrm{C}-10$.

The geometry of all three 1,2-disubstituted double bonds in 2 was assigned as $E$ based on observation of a $15-\mathrm{Hz} J$ value in each case. The trisubstituted double bond was also assigned the $E$-geometry on the basis of the carbon chemical shift for the $16-\mathrm{CH}_{3}(\delta$ 13.1) [7]. The relative stereochemistry of the ring in $\mathbf{2}$, and the stereocenters at $\mathrm{C} 2 \sim \mathrm{C} 3$ and $\mathrm{C} 14 \sim \mathrm{C} 15$ was presumed to be the same as that in $\mathbf{1}$ on the basis of close similarities in the NMR data.

$\mathbf{1}$ and $\mathbf{2}$ were tested for activity against $A$. flavus (NRRL 6541) in a disk diffusion assay [9]. After 48 hours at $200 \mu \mathrm{g} /$ disk, a 22-mm clear inhibition zone was observed for 1 and an 18-mm zone of reduced growth was observed for 2. MIC and $\mathrm{IC}_{50}$ values were determined for $\mathbf{1}$ as $25 \mu \mathrm{g} / \mathrm{ml}$ and $6 \mu \mathrm{g} / \mathrm{ml}$, respectively, with a $10 \mu \mathrm{g} / \mathrm{ml}$ concentration showing 94\% reduction in growth. These results were comparable to those obtained for nystatin using the same protocol. $\mathbf{1}$ and $\mathbf{2}$ also showed activity in standard disk assays against Staphylococcus aureus (ATCC 29213) and Candida albicans (ATCC 14053). Both compounds afforded $8 \sim 9 \mathrm{~mm}$ zones of inhibition against $S$. aureus at $25 \mu \mathrm{g} /$ disk. Sporminarin A showed an 11-mm zone of inhibition against $C$. albicans at the $25 \mu \mathrm{g} / \mathrm{disk}$ level, while $50 \mu \mathrm{g}$ of sporminarin $\mathrm{B}$ was required to afford the same effect. The known compound brocaenol A, also obtained from the $S$. minimoides extract, is known to display moderate cytotoxicity [5].

$\mathbf{1}$ and $\mathbf{2}$ belong to a class of polyketide-type fungal metabolites that are characterized by highly methylated and hydroxylated open-chain structures. Most of the compounds of this class have either pentitol or hexitol units incorporated into their structures via ester linkages at one of the termini, and cyclic sugars that form ether bonds with one of the open-chain hydroxy groups. Representative examples include roselipins [10], TMC-151 A $\sim \mathrm{F}$ [7], and cladionol A [6]. Cameronic acid, cubensic acid, berteric acid, and malaysic acid, isolated from Xylaria spp. [11, 12], are among the few examples of this type that lack sugar units. The $\mathrm{C} 1 \sim \mathrm{C} 17$ side-chain in 2 is identical to the corresponding unit in the structure of cameronic acid. However, to our knowledge, the occurrence of a cyclic subunit like that found in $\mathbf{1}$ and $\mathbf{2}$ has not been previously reported in members of this class. By analogy to the results of a biosynthetic study reported for cubensic acid [13], 1 and $\mathbf{2}$ are likely to be biosynthetically derived from acetate units, with the methyl substituents along the chain arising from $S$-adenosylmethionine. Chemical studies of the genus Sporormiella are relatively rare, and to our knowledge, there is only one prior report of chemistry (an unrelated antifungal agent) from $S$. minimoides [14].

\section{Experimental}

\section{General Experimental Procedures}

Melting points were recorded with a Fisher-Johns melting point apparatus and are uncorrected. Optical rotations were measured with a Rudolph Research Autopol III automatic polarimeter. IR spectra were recorded using a Perkin-Elmer Spectrum BX FT-IR instrument. ${ }^{1} \mathrm{H}$ NMR spectra were acquired on a Bruker Avance-600 or a Bruker DRX-400 instrument. ${ }^{13} \mathrm{C}$ NMR and DEPT spectra were recorded using the DRX-400, while HMBC, HMQC, and NOESY data were recorded on the Avance-600. All NMR spectra were referenced to residual solvent signals $\left(\mathrm{CD}_{3} \mathrm{OD} ; \delta_{\mathrm{H}}\right.$ $\left.3.31 / \delta_{\mathrm{C}} 49.15\right)$. Mass spectra were recorded with either a ThermoFinnigan LCQ ion trap (ESIMS) or a Micromass Autospec mass spectrometer (HRESIMS). HPLC purification of brocaenol A was carried out using a semipreparative Alltech C18 column $(250 \times 10 \mathrm{~mm}, 8-\mu \mathrm{m}$ particles) with a Beckman $127 \mathrm{P}$ solvent module and a Beckman System Gold 166 diode array detector. Sporminarins A (1) and B (2) were purified using a Hamilton PRP-1 column $(250 \times 10 \mathrm{~mm}, 10-\mu \mathrm{m}$ particles $)$ with a Beckman 110B solvent module and a Beckman System Gold 166 diode array detector.

\section{Fungal Material}

A culture (MYC-1545) of the fungicolous fungus Sporormiella minimoides Ahmed \& Cain (Sporormiaceae) was isolated by DTW from a basidioma of the polypore Trametes hirsutum that was collected by DTW from a dead hardwood branch in Mamane (Sophora) subalpine forest, Pu'u la'au, Highway 200 (Milepost 43), Hawaii County, HI on November 2, 2002. A subculture of this isolate has been deposited with the ARS Culture Collection at the U.S. National Center for Agricultural Utilization Research in Peoria, Illinois with the accession number NRRL 37629.

\section{Fermentation, Extraction, and Isolation}

Fermentation and extraction processes were carried out using general procedures that have been described elsewhere [15]. Solid-state fermentation was carried out in six 500-ml Erlenmeyer flasks each containing $50 \mathrm{~g}$ of rice. The crude EtOAc extract $(831 \mathrm{mg}$ ) of the resulting cultures was partitioned between $\mathrm{MeOH}-\mathrm{CH}_{3} \mathrm{CN}$ (1:1) and hexanes. The $\mathrm{MeOH}-\mathrm{CH}_{3} \mathrm{CN}$-soluble portion (536 mg) was subjected to silica gel column chromatography, eluting successively with $\mathrm{CH}_{2} \mathrm{Cl}_{2}-\mathrm{MeOH}(9: 1,300 \mathrm{ml} ; 17: 3$, $150 \mathrm{ml} ; 4: 1,200 \mathrm{ml} ; 3: 1,100 \mathrm{ml} ; 7: 3,100 \mathrm{ml} ; 3: 2$, $100 \mathrm{ml} ; 1: 1,200 \mathrm{ml})$ to afford 11 fractions. Reversed-phase HPLC of a portion $(24 \mathrm{mg})$ of silica gel fraction $2(72 \mathrm{mg})$ 
eluting with $\mathrm{CH}_{3} \mathrm{CN}$ and $\mathrm{H}_{2} \mathrm{O}\left(50 \% \mathrm{CH}_{3} \mathrm{CN}\right.$ over 25 minutes, $50 \%$ to $100 \% \mathrm{CH}_{3} \mathrm{CN}$ over 2 minutes, $100 \%$ $\mathrm{CH}_{3} \mathrm{CN}$ over 30 minutes) at $2.0 \mathrm{ml} /$ minute and $\mathrm{UV}$ detection at $215 \mathrm{~nm}$ afforded brocaenol $\mathrm{A}(10 \mathrm{mg}$; $\mathrm{Rt}=12$ minutes). Reversed-phase HPLC of fraction $8(25 \mathrm{mg})$ eluting with $\mathrm{CH}_{3} \mathrm{CN}$ and $\mathrm{H}_{2} \mathrm{O}$ acidified with $0.1 \%$ formic acid $\left(50 \% \mathrm{CH}_{3} \mathrm{CN}\right.$ over 10 minutes, $50 \%$ to $75 \% \mathrm{CH}_{3} \mathrm{CN}$ over 15 minutes, and $75 \%$ to $100 \% \mathrm{CH}_{3} \mathrm{CN}$ over 1 minute) at $2.0 \mathrm{ml} /$ minute and $\mathrm{UV}$ detection at $212 \mathrm{~nm}$ afforded pure sporminarin $\mathrm{A}(\mathbf{1} ; 10 \mathrm{mg} ; \mathrm{Rt}=24.6$ minutes $)$ and sporminarin $\mathrm{B}(\mathbf{2} ; 2.8 \mathrm{mg} ; \mathrm{Rt}=21.4$ minutes $)$. Fractions 5 $(44 \mathrm{mg})$ and $10(44 \mathrm{mg})$ from the silica gel column were also subjected to reversed-phase HPLC under identical conditions to obtain additional quantities of $1(17 \mathrm{mg}$ and $12 \mathrm{mg}$ from fractions 5 and 10 , respectively) and 2 (12 mg from fraction 10).

\section{Sporminarin A (1)}

White amorphous solid; $[\alpha]_{\mathrm{D}}+19(c$ o.6, MeOH); mp $174 \sim 175^{\circ} \mathrm{C}$; IR (KBr) $v_{\max } 3400,1721 \mathrm{~cm}^{-1} ;{ }^{1} \mathrm{H}$ NMR, ${ }^{13} \mathrm{C}$ NMR, and HMBC data, see Table 1; selected NOESY data $\left(\mathrm{CD}_{3} \mathrm{OD}, 600 \mathrm{MHz}\right) \mathrm{H}-2 \leftrightarrow 2-\mathrm{CH}_{3} ; \mathrm{H}-3 \leftrightarrow 2-\mathrm{CH}_{3}, \mathrm{H}-5 ; \mathrm{H}-$ $5 \leftrightarrow 6-\mathrm{CH}_{3} ; \mathrm{H}-6 \leftrightarrow \mathrm{H}-7,6-\mathrm{CH}_{3} ; \mathrm{H}-7 \leftrightarrow 6-\mathrm{CH}_{3} ; \mathrm{H}-10 \leftrightarrow 10-$ $\mathrm{CH}_{3}, \quad \mathrm{H}-11 ; \quad \mathrm{H}-11 \leftrightarrow 10-\mathrm{CH}_{3} ; \quad \mathrm{H}-14 \leftrightarrow \mathrm{H}-15, \quad 14-\mathrm{CH}_{3}$, $16-\mathrm{CH}_{3} ; \mathrm{H}-15 \leftrightarrow \mathrm{H}-17, \quad 14-\mathrm{CH}_{3}, \quad 16-\mathrm{CH}_{3} ; \mathrm{H}-17 \leftrightarrow \mathrm{H}-19$, $14-\mathrm{CH}_{3}, 18-\mathrm{CH}_{3} ; \mathrm{H}-19 \leftrightarrow \mathrm{H}-21 \alpha, \mathrm{H}-23 \mathrm{~b}, 16-\mathrm{CH}_{3}, 20-\mathrm{CH}_{3}$; $\mathrm{H}-20 \leftrightarrow 18-\mathrm{CH}_{3}, \quad 20-\mathrm{CH}_{3}, \quad 22-\mathrm{CH}_{3} ; \quad \mathrm{H}-21 \beta \leftrightarrow 20-\mathrm{CH}_{3}$; $4-\mathrm{CH}_{3} \leftrightarrow 2-\mathrm{CH}_{3}, 6-\mathrm{CH}_{3} ; 16-\mathrm{CH}_{3} \leftrightarrow 14-\mathrm{CH}_{3}, 18-\mathrm{CH}_{3} ; 18-$ $\mathrm{CH}_{3} \leftrightarrow 22-\mathrm{CH}_{3}$; HRESIMS obsd $m / z 645.4373(\mathrm{M}+\mathrm{Na})^{+}$, calcd for $\mathrm{C}_{36} \mathrm{H}_{62} \mathrm{O}_{8} \mathrm{Na}, 645.4342$.

\section{Sporminarin B (2)}

White amorphous solid; $[\alpha]_{\mathrm{D}}^{25}+12(c \quad 0.7, \mathrm{MeOH}) ; \mathrm{mp}$ $185 \sim 186{ }^{\circ} \mathrm{C}$; IR (KBr) $v_{\max } 3393,1719 \mathrm{~cm}^{-1}$; ${ }^{1} \mathrm{H} \mathrm{NMR},{ }^{13} \mathrm{C}$ NMR, and HMBC data (see Table 1); HRESIMS obsd $\mathrm{m} / \mathrm{z}$ $631.4182(\mathrm{M}+\mathrm{Na})^{+}$, calcd for $\mathrm{C}_{35} \mathrm{H}_{60} \mathrm{O}_{8} \mathrm{Na}, 631.4186$.

\section{Acetylation of Sporminarin A (1)}

Acetic anhydride $(0.5 \mathrm{ml})$ was added to a solution of $\mathbf{1}$ $(2.3 \mathrm{mg})$ in pyridine $(0.5 \mathrm{ml})$, and the reaction mixture was stirred at room temperature for 24 hours. Saturated aqueous solution of $\mathrm{NaHCO}_{3}(2 \mathrm{ml})$ was then added and the solution was extracted with $\mathrm{CH}_{2} \mathrm{Cl}_{2}(2 \mathrm{ml} \times 3)$. The organic layer was then filtered through anhydrous $\mathrm{MgSO}_{4}$ and dried under an air flow to obtain the pentaacetate $(3 ; 3.1 \mathrm{mg})$; colorless glass; ${ }^{1} \mathrm{H}$ NMR $\left(\mathrm{CD}_{3} \mathrm{OD}, 400 \mathrm{MHz}\right) \delta 5.62(1 \mathrm{H}, \mathrm{dd}, 15$, $7.9 \mathrm{~Hz}), 5.55(1 \mathrm{H}, \mathrm{dd}, 15,8.1 \mathrm{~Hz}), 5.41(3 \mathrm{H}, \mathrm{m}), 5.35(1 \mathrm{H}$, br s), $5.18(1 \mathrm{H}, \mathrm{d}, 10.3 \mathrm{~Hz}), 5.03(1 \mathrm{H}, \mathrm{t}, 7 \mathrm{~Hz}), 5.02(1 \mathrm{H}, \mathrm{t}$, $7 \mathrm{~Hz}), 4.76(1 \mathrm{H}, \mathrm{d}, 8.4 \mathrm{~Hz}), 4.68(1 \mathrm{H}, \mathrm{d}, 10.7 \mathrm{~Hz}), 2.73(1 \mathrm{H}$, $\mathrm{m}), 2.70(1 \mathrm{H}$, dquintet, 9.7, $7 \mathrm{~Hz}), 2.47(1 \mathrm{H}, \mathrm{m}), 2.39(1 \mathrm{H}$, m), $2.06(3 \mathrm{H}, \mathrm{s}), 1.994(3 \mathrm{H}, \mathrm{s}), 1.99(3 \mathrm{H}, \mathrm{s}), 1.98(3 \mathrm{H}, \mathrm{s})$,
$1.98(1 \mathrm{H}$, overlapped), $1.97(3 \mathrm{H}, \mathrm{s}), 1.85(3 \mathrm{H}, \mathrm{d}, 1.2 \mathrm{~Hz})$, $1.63(3 \mathrm{H}, \mathrm{d}, 1.1 \mathrm{~Hz}), 1.63(2 \mathrm{H}, \mathrm{m}), 1.44(2 \mathrm{H}, \mathrm{m}), 1.41(3 \mathrm{H}$, s), $1.32(3 \mathrm{H}, \mathrm{s}), 1.32(1 \mathrm{H}, \mathrm{m}), 1.29(1 \mathrm{H}, \mathrm{dd}, 14,6.4 \mathrm{~Hz})$, $1.14(1 \mathrm{H}$, dquintet, 14, $7.4 \mathrm{~Hz}), 1.02(3 \mathrm{H}, \mathrm{d}, 6.8 \mathrm{~Hz}), 0.98$ $(3 \mathrm{H}, \mathrm{d}, 6.9 \mathrm{~Hz}), 0.94(3 \mathrm{H}, \mathrm{d}, 7 \mathrm{~Hz}), 0.92(3 \mathrm{H}, \mathrm{d}, 7 \mathrm{~Hz}), 0.89$ $(3 \mathrm{H}, \mathrm{d}, 7.1 \mathrm{~Hz}), 0.87(3 \mathrm{H}, \mathrm{d}, 6.4 \mathrm{~Hz}), 0.86(3 \mathrm{H}, \mathrm{t}, 7.4 \mathrm{~Hz})$; ESIMS obsd $m / z 855(\mathrm{M}+\mathrm{Na})^{+}$for $\mathrm{C}_{46} \mathrm{H}_{72} \mathrm{O}_{13} \mathrm{Na}$.

\section{Methylation of Sporminarin A (1)}

Trimethylsilyldiazomethane ( $80 \mu 1$ of a $2 \mathrm{M}$ solution in hexanes) was added to a solution of $\mathbf{1}(1 \mathrm{mg})$ in $\mathrm{MeOH}$ $(500 \mu \mathrm{l})$, and the solution was stirred at room temperature. The reaction was monitored by TLC and by discoloration of the initial yellow solution. After 25 minutes, the solution was dried under air flow to obtain the methyl ester of $\mathbf{1}$ (4; $1 \mathrm{mg})$; white amorphous solid; ${ }^{1} \mathrm{H}$ NMR $\left(\mathrm{CD}_{3} \mathrm{OD}\right.$, $400 \mathrm{MHz}) \delta 5.64(\mathrm{dd}, 15,7.9 \mathrm{~Hz}, \mathrm{H}-9), 5.63$ (dd, 15, $7.9 \mathrm{~Hz}, \mathrm{H}-13$ ), 5.62 (br s, H-17), 5.49 (br dd, 15, $7 \mathrm{~Hz}, \mathrm{H}-8$, H-12), 5.32 (dd, 9.6, 1.3 Hz, H-5), 4.04 (d, $9.8 \mathrm{~Hz}, \mathrm{H}-3$ ), 3.84 (t, $7 \mathrm{~Hz}, \mathrm{H}-11), 3.83$ (t, $7 \mathrm{~Hz}, \mathrm{H}-7), 3.57$ (d, $8.8 \mathrm{~Hz}, \mathrm{H}-$ 15), $3.69\left(\mathrm{~s}, 1-\mathrm{OCH}_{3}\right), 3.00$ (d, $\left.10.6 \mathrm{~Hz}, \mathrm{H}-19\right), 2.61$ (dq, 9.8, $7.1 \mathrm{~Hz}, \mathrm{H}-2), 2.52$ (dquintet, 9.6, $7 \mathrm{~Hz}, \mathrm{H}-6), 2.30$ (m, H-14), 2.25 (m, H-10), 1.95 (m, H-20), 1.83 (d, 1.2 Hz, 16$\left.\mathrm{CH}_{3}\right), 1.61$ (d, $\left.1.3 \mathrm{~Hz}, 4-\mathrm{CH}_{3}\right), 1.60$ (m, H-24), 1.55 (13, $3.7 \mathrm{~Hz}, \mathrm{H}-21 \beta), 1.40$ (s, 18- $\left.\mathrm{CH}_{3}\right), 1.40$ (m, H-23a, H-25a), $1.30\left(\mathrm{~s}, 22-\mathrm{CH}_{3}\right), 1.30(\mathrm{~m}, \mathrm{H}-21 \alpha), 1.27$ (dd, 14, 6.4 Hz, H23b), 1.14 (dquintet, 14, 7.4 Hz, H-25b), 1.02 (d, $6.3 \mathrm{~Hz}$, $\left.20-\mathrm{CH}_{3}\right), 0.99\left(\mathrm{~d}, 6.9 \mathrm{~Hz}, 10-\mathrm{CH}_{3}\right), 0.94\left(\mathrm{~d}, 7.1 \mathrm{~Hz}, 2-\mathrm{CH}_{3}\right)$, $0.92\left(\mathrm{~d}, 7 \mathrm{~Hz}, 6-\mathrm{CH}_{3}, 24-\mathrm{CH}_{3}\right), 0.87\left(\mathrm{~d}, 6.7 \mathrm{~Hz}, 14-\mathrm{CH}_{3}\right)$, 0.85 (t, $\left.7.4 \mathrm{~Hz}, \mathrm{H}_{3}-26\right)$; ESIMS obsd $m / z 659(\mathrm{M}+\mathrm{Na})^{+}$for $\mathrm{C}_{37} \mathrm{H}_{64} \mathrm{O}_{8} \mathrm{Na} ; m / z 635(\mathrm{M}-\mathrm{H})^{-}$for $\mathrm{C}_{37} \mathrm{H}_{63} \mathrm{O}_{8}$.

\section{Deuterium-exchange MS Experiment}

Samples of sporminarin A $(\mathbf{1} ; 0.3 \mathrm{mg})$ and its pentaacetate (3; $0.4 \mathrm{mg}$ ) were dissolved in $\mathrm{CD}_{3} \mathrm{OD}$ and dried under air flow. This procedure was repeated four times for each sample. A $1: 1$ mixture of $\mathrm{CD}_{3} \mathrm{OD}$ and $\mathrm{D}_{2} \mathrm{O}$ was used to dissolve each sample for ESIMS ionization; sporminarin A (1); obsd $m / z 651(\mathrm{M}+\mathrm{Na})^{+}$for $\mathrm{C}_{36} \mathrm{H}_{56} \mathrm{D}_{6} \mathrm{O}_{8} \mathrm{Na}$, and $m / z$ $626(\mathrm{M}-\mathrm{D})^{-}$for $\mathrm{C}_{36} \mathrm{H}_{56} \mathrm{D}_{5} \mathrm{O}_{8}$; pentaacetate 3 ; obsd $m / z 856$ $(\mathrm{M}+\mathrm{Na})^{+}$for $\mathrm{C}_{46} \mathrm{H}_{71} \mathrm{DO}_{13} \mathrm{Na}$, and $m / z 831(\mathrm{M}-\mathrm{D})^{-}$for $\mathrm{C}_{46} \mathrm{H}_{71} \mathrm{O}_{13}$.

\section{MIC and $\mathrm{IC}_{\mathbf{5 0}}$ Determination}

Aspergillus flavus (NRRL 6541) was grown in Roux bottles containing potato dextrose agar (PDA) for 14 days $\left(25^{\circ} \mathrm{C}\right)$. A conidial spore suspension (propagule density $10^{6} / \mathrm{ml}$ in sterile distilled $\mathrm{H}_{2} \mathrm{O}$ ) prepared from the Roux bottle cultures served as the inoculum. Hyphal fragments and conidium-bearing structures were removed by filtering through a double layer of sterile cheese cloth. Compounds 
were evaluated in 96-well plates with a growth area of $0.32 \mathrm{~cm}^{2}$ and volume of $370 \mu \mathrm{l}$ (BD Primaria Clear 96-well Microtest Plate No. 353872, Becton Dickinson) at concentrations of $0.25,1,2,3,5,10,25$, and $50 \mu \mathrm{g} / \mathrm{ml}$. Appropriate amounts of the test compound in $10 \mu \mathrm{l}$ of $\mathrm{MeOH}$ were added to each of eight replicate wells and evaporated to dryness. Eight replicate wells received only $10 \mu \mathrm{l} \mathrm{MeOH}$ and served as controls. Potato dextrose broth (PDB) was seeded with A. flavus conidia, giving a final conidial suspension of approximately $4 \times 10^{4} / \mathrm{ml}$ PDB. A small quantity of $\mathrm{MeOH}(10 \mu \mathrm{l})$ was added to each well to solubilize the test compound, and then $200 \mu \mathrm{l}$ of PDB containing $c a$. 8,000 A. flavus conidia was added to each test well. The plates were incubated for 48 hours at $25^{\circ} \mathrm{C}$ and examined at $8 \sim 16$ hours intervals using a plate reader (Dynatech MR 5000 with BioLinx Version 2.0 Assay Management Software; Dynatech Laboratories, Inc.) for evidence of inhibition of fungal growth in the wells. A minimum inhibitory concentration (MIC) was assigned to the lowest treatment concentration for which no fungal growth was observed, while an $\mathrm{IC}_{50}$ was designated when fungal growth was approximately $50 \%$ of that recorded for the $\mathrm{MeOH}$-only control wells. Nystatin was used as a positive control, and gave $\mathrm{MIC}$ and $\mathrm{IC}_{50}$ values of approximately 10 and $5 \mu \mathrm{g} / \mathrm{ml}$, respectively, using this protocol.

Acknowledgments The authors thank the staff of the University of Iowa MS and NMR facilities for their assistance. We are also grateful to Professor Don Hemmes of the University of Hawaii at Hilo for guiding the collection of fungal sporocarps from Hawaii. Financial support for this project from the National Institutes of Health (GM 60600) is greatly appreciated.

References

1. Shim SH, Swenson DC, Gloer JB, Dowd PF, Wicklow DT. Penifulvin A: A sesquiterpenoid-derived metabolite containing a novel dioxa[5,5,5,6]fenestrane ring system from a fungicolous isolate of Penicillium griseofulvum. Org Lett 8: 1225-1228 (2006)

2. Jiao P, Swenson DC, Gloer JB, Wicklow DT. Chloriolide, a 12-membered macrolide from Chloridium virescens var. chlamydosporum (NRRL 37636). J Nat Prod 69: 636-639 (2006)

3. Deyrup ST, Swenson DC, Gloer JB, Wicklow DT. Caryophyllene sesquiterpenoids from a fungicolous isolate of Pestalotiopsis disseminata. J Nat Prod 69: 608-611 (2006)
4. Reátegui RF, Gloer JB, Wicklow DT. Phaeofurans and sorbicillin analogues from a fungicolous Phaeoacremonium species (NRRL 32148). J Nat Prod 69: 113-117 (2006)

5. Bugni TS, Bernan VS, Greenstein M, Janso JE, Maiese WM, Mayne CL, Ireland CM. Brocaenols A C: Novel polyketides from a marine-derived Penicillium brocae. J Org Chem 68: 2014-2017 (2003)

6. Kasai Y, Komatsu K, Shigemori H, Masashi T, Mikami Y, Kobayashi J. Cladionol A, a polyketide glycoside from marine-derived fungus Gliocladium species. J Nat Prod 68: 777-779 (2005)

7. Kohno J, Nishio M, Sakurai M, Kawano K, Hiramatsu H, Kameda N, Kishi N, Yamashita T, Okuda T, Komatsubara S. Isolation and structure determination of TMC-151s: Novel polyketide antibiotics from Gliocladium catenulatum Gilman \& Abbott TC 1280. Tetrahedron 55: 7771-7786 (1999)

8. Matsumori N, Kaneno D, Murata M, Nakamura H, Tachibana K. Stereochemical determination of acyclic structures based on carbon-proton spin-coupling constants. A method of configuration analysis for natural products. J Org Chem 64: 866-876 (1999)

9. Wicklow DT, Joshi BK, Gamble WR, Gloer JB, Dowd PF. Antifungal metabolites (monorden, monocillin IV, and cerebrosides) from Humicola fuscoatra Traaen NRRL 22980, a mycoparasite of Aspergillus flavus sclerotia. Appl Environ Microbiol 64: 4482-4484 (1998)

10. Tabata N, Ohyama Y, Tomoda H, Abe T, Namikoshi M, Ōmura S. Structure elucidation of roselipins, inhibitors of diacylglycerol acyltransferase produced by Gliocladium roseum KF-1040. J Antibiot 52: 815-826 (1999)

11. Adeboya MO, Edwards RL, Laessoe T, Maitland DJ. Metabolites of the higher fungi. Part 27. Berteric acid, cameronic acid and malaysic acid, three new polysubstituted fatty acids related to cubensic acid from species of the fungus genus Xylaria. J Chem Res Syn 9: 356-357 (1995)

12. Edwards RL, Maitland DJ, Whalley AJS. Metabolites of the higher fungi. Part 26. Cubensic acid, 3,7,11,15-tetrahydroxy18-(hydroxymethyl)-2,4,6,10,14,16,20-heptamethyldocosa$4 \mathrm{E}, 8 \mathrm{E}, 12 \mathrm{E}, 16 \mathrm{E}$-tetraenoic acid, a novel polysubstituted $\mathrm{C}_{22}$ fatty acid from the fungus Xylaria cubensis (Mont.) Fr. with substituents and substitution pattern similar to the macrolide antibiotics. J Chem Soc Perkin Trans I 6: 1411-1417 (1991)

13. O'Hagan D, Rogers SV, Duffin GR, Edwards RL. Biosynthesis of the fungal polyketide cubensic acid from Xylaria cubensis. Tetrahedron Lett 33: 5585-5588 (1992)

14. Clapp-Shapiro WH, Burgess BW, Giacobbe RA, Harris GH, Mandala S, Polishook J, Rattray M, Thornton RA, Zink DL, Cabello A, Diez MT, Martin I, Pelaez F. U.S. Patent 5,801,172, September, 1998

15. Soman AG, Gloer JB, Angawi RF, Wicklow DT, Dowd PF. Vertilecanins: New phenopicolinic acid analogues from Verticillium lecanii. J Nat Prod 64: 189-192 (2001) 